GENERAL ENGINEERING DRAWING EXAMPLES 


\section{GENERAL ENGINEERING DRAWING EXAMPLES}

H. ORD

T. ENG. (CEI), MI. PLANT E., FIED., ARAeS., CERT. ED. 
(C) H. Ord 1973

All rights reserved. No part of this publication may be reproduced or transmitted, in any form or by any means, without permission

First published 1973 by

THE MACMILLAN PRESS LTD

London and Basingstoke

Associated companies in New York Dublin

Melbourne Johannesburg and Madras

SBN 333148878

ISBN 978-0-333-14887-7

ISBN 978-1-349-01911-3 (eBook)

DOI 10.1007/978-1-349-01911-3

The paperback edition of this book is sold subject to the condition that it shall not, by way of trade or otherwise, be lent, re-sold, hired out, or otherwise circulated without the publisher's prior consent in any form of binding or cover other than that in which it is published and without a similar condition including this condition being imposed on the subsequent purchaser. 


\section{CONTENTS}

Preface

1 Triangles, quadrilaterals and circles

2 Ellipses

3 Loci

4 True shapes and developments

5 Dimensioning

6 Orthographic projection

(a) First angle (European) projection

(b) Third angle (American) projection

7 Orthographic and pictorial projection

8 Freehand sketching

9 Electrical work

10 Drawing exercises

Appendix: Extracts from BS 308: Part 1: 1972 


\section{PREFACE}

This book is entirely in SI units, and has been specially prepared to be used by all students taking basic Engineering Drawing. Students and lecturers alike can use it for classwork and for homework examples. My thanks are due to:

(a) my senior students, Messrs Lamming, Prosser, Howlett, Claridge, Grainger, Salt and Wainwright who have drawn out many of the examples;

(b) my friend and former colleague Mr P. G. W. Astley, who has checked the script;

(c) my wife Tessa, who, besides typing the script, has carried out many other tasks to prepare the book for publication;

(d) the publishers and production team for their helpful comments and suggestions.

Extracts from B.S. 308: Engineering Drawing Practice: Part I: 1972 General Principles, are reproduced by permission of the British Standards Institution, 2 Park Street, London W1A 2BS.

H. ORD 